\title{
Ultrasound in children and adolescents with inflammatory bowel disease
}

\author{
Francesco La Seta ${ }^{1 *}$, Michele Citrano², Lorenzo Tesè ${ }^{1}$, Lucrezia Bruno ${ }^{3}$ \\ From 70th Congress of the Italian Society of Pediatrics, Joint National Meeting SIP, SICuPP, SITIP \\ Palermo, Italy. 11-14 June 2014
}

The term Inflammatory Bowel Disease (IBD) is used to describe several idiopathic gastrointestinal disorders; among these diseases, the most commonly encountered in clinical practice are Crohn's Disease (CD) and Ulcerative Colitis (UC).

$\mathrm{CD}$ and $\mathrm{UC}$ are different both in distribution of gastrointestinal tract involvement and depth of inflammation. $25 \%$ of patients reveals IBD during childhood or adolescence [1].

No consensus exists regarding the optimal techniques and imaging modalities when evaluating IBD, especially in the paediatric age. [2] The correct imaging choice often depends on clinical presentation of patients. The most common situations are: the initial diagnosis of suspected IBD; patients with known IBD presenting with acute symptoms; follow-up of patients with or without new symptoms [2].

Multiple methods can be used to diagnose and examine paediatric patients with IBD, including Computed Tomography (CT), Magnetic Resonance (MR), Small Bowel Follow-through radiographic examination (SBFT), Endoscopy, and Ultrasound (US) $[3,4]$.

While UC is mainly clinically managed with endoscopy and US, CD very often needs cross-sectional imaging to assess the exact distribution and activity of the disease, and to detect extraluminal complications (phlegmon, abscess, fistula, bowel perforation).

Due to early onset of disease, paediatric patients obviously need additional attention to minimize radiation exposure: it is mandatory to avoid unnecessary ionizing radiation techniques in IBD imaging [2-4].

Consequence of the foregoing statements, US and (more recently) MR-enterography have become the

\footnotetext{
* Correspondence: flaset@tin.it

'Dept. of Radiology, V. Cervello' Hospital - A.O.R. 'Villa Sofia - Cervello,

Palermo, Italy
}

Full list of author information is available at the end of the article preferred imaging modalities in management of young patients with IBD [2-6].

In clinical practice, in Europe, US is currently the first examination requested to evaluate patients with abdominal symptoms. US is accurate in diagnosis of several paediatric (intestinal and non-intestinal) diseases; US may also help when selecting patients needing additional caring among children suffering from gastroenteric tract diseases. [5] Furthermore, US may offer information that are difficult to obtain with other diagnostic modalities, and in fact it is the only technique which could possibly investigate in real time all the followings: the morphological and functional aspects of the bowel wall, the vascularisation (with color-Doppler) of thickened bowel, the stiffness of intestinal loops, and perivisceral spaces [5].

The aim of this review is to elucidate the current role of US in diagnosis and follow-up of paediatric patients with $\mathrm{UC}$ and $\mathrm{CD}$, and to discuss the advantages and disadvantages of this radiation-free imaging methods in terms of cost, safe, diagnostic accuracy and accessibility compared with other diagnostic modalities.

\section{Authors' details}

'Dept. of Radiology, 'V. Cervello' Hospital - A.O.R. 'Villa Sofia - Cervello, Palermo, Italy. ${ }^{2}$ Dept of Pediatrics, V. Cervello' Hospital - A.O.R. 'Villa Sofia Cervello, Palermo, Italy. ${ }^{3}$ Specialty in Pediatrics, University of Palermo, Italy.

Published: 11 August 2014

\section{References}

1. Griffiths AM: Specificities of inflammatory bowel disease in childhood. Best Pract Res Clin Gastroenterol 2004, 18:509-523.

2. Duigenan S, Gee MS: Imaging of Pediatric Patients with Inflammatory Bowel Disease. AJR 2012, 199:907-915.

3. Towbin AJ, Sullivan J, Denson LA, Wallihan DB, Podberesky DJ: CT and MR Enterography in Children and Adolescents with Inflammatory Bowel Disease. RadioGraphics 2013, 33:1843-1860.

4. Panes J, Bouhnik Y, Reinisch W, Stoker J, Taylor SA, Baumgart DC, Danese S, Halligan S, Marincek B, Matos C, Peyrin-Biroulet L, Rimola J, Rogler G, van Assche G, Ardizzone S, Ba-Ssalamah A, Bali MA, Bellini D, Biancone L, 
Castigiione F, Ehehalt R, Grassi R, Kucharzik T, Maccioni F, Maconi G,

Magro F, Martín-Comín J, Morana G, Pendsé D, Sebastian S, Signore A,

Tolan D, Tielbeek JA, Weishaupt D, Wiarda B, Laghi A: Imaging techniques

for assessment of inflammatory bowel disease: Joint ECCO and ESGAR

evidence-based consensus guidelines. J Crohns Colitis 2013, 7:556-585.

5. Cammarota T, Sarno A, Robotti D, Bonenti G, Debani P, Versace K,

Astegiano M, Pera A: US evaluation of patients affected by IBD: how to

do it, methods and findings. Eur J Rad 2009, 69:429-437.

6. Novak KL, Wilson SR: Sonography for Surveillance of Patients with Crohn Disease. J Ultrasound Med 2012, 31:1147-1152.

doi:10.1186/1824-7288-40-S1-A28

Cite this article as: La Seta et al:: Ultrasound in children and adolescents with inflammatory bowel disease. Italian Journal of Pediatrics 201440

(Suppl 1):A28.

\section{Submit your next manuscript to BioMed Central} and take full advantage of:

- Convenient online submission

- Thorough peer review

- No space constraints or color figure charges

- Immediate publication on acceptance

- Inclusion in PubMed, CAS, Scopus and Google Scholar

- Research which is freely available for redistribution

Submit your manuscript at www.biomedcentral.com/submit 